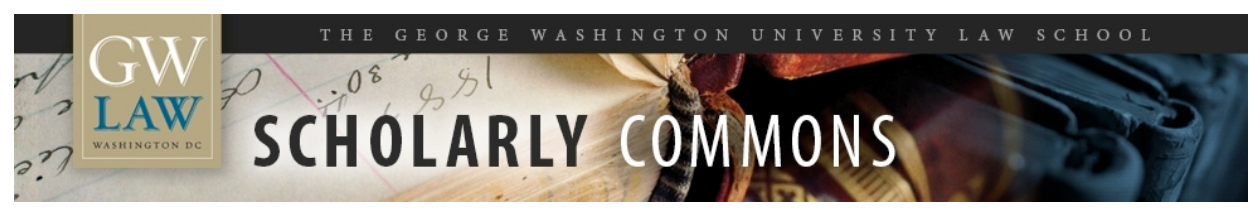

\title{
Jurisgenerative Constitutionalism: Procedural Principles for Managing Global Legal Pluralism
}

Paul Schiff Berman

George Washington University Law School, pberman@law.gwu.edu

Follow this and additional works at: https://scholarship.law.gwu.edu/faculty_publications

Part of the Law Commons

\section{Recommended Citation}

Paul Schiff Berman, Jurisgenerative Constitutionalism: Procedural Principles for Managing Global Legal Pluralism, 20 IND. J. GLOBAL LEGAL STUD. 1 (2013).

This Article is brought to you for free and open access by the Faculty Scholarship at Scholarly Commons. It has been accepted for inclusion in GW Law Faculty Publications \& Other Works by an authorized administrator of Scholarly Commons. For more information, please contact spagel@law.gwu.edu. 


\title{
Jurisgenerative Constitutionalism: Procedural Principles for Managing Global Legal Pluralism
}

\author{
PAUl SCHIFF BERMAN*
}

\begin{abstract}
Global Legal Pluralism recognizes the inevitability (and sometimes even the desirability) of multiple legal and quasi-legal systems purporting to regulate the same act or actor. However, the resulting pluralism-just as inevitably_creates conflicts among norms that are potentially intractable. Thus, legal systems must address how best to respond to the realities of pluralism. This inquiry has constitutional dimensions because it goes to the constitutive character of communities and their relationships with other communities, be they international, transnational, national, subnational, or epistemic.

One response to pluralism is jurispathic: "kill off" all competing laws by declaring that one set of norms-and only one-shall win. This is a constitutional declaration founded solely on power or messianism, and I argue that it is both unsatisfying as a normative matter and doomed to failure as a descriptive one.

Instead, this article offers principles that would undergird a more jurisgenerative constitutionalism, one that seeks to manage, without eliminating, the plural voices clamoring to be heard. These principles can be used to design procedural mechanisms, institutions, and discursive practices that better respond to the reality of a world of multiple competing voices. In addition, such principles may bring more such voices into the constitutional discourse, thereby creating at least the possibility that enemies can be turned into adversaries, resulting in more fruitful (and peaceful) constitutional interactions.
\end{abstract}

* Manatt/Ahn Professor of Law, The George Washington University Law School. This article is based on a presentation at a conference on transnational societal constitutionalism held in Turin, Italy in May 2012. It builds on, and includes material from, my recent book, Global Legal Pluralism: A JURISPRUdence of LAW Beyond BORDERS (Cambridge 2012), as well as several articles that preceded the book.

Indiana Journal of Global Legal Studies Vol. 20, Issue 2 (2013)

(C) Indiana University Maurer School of Law 


\section{INTRODUCTION}

When two communities or social systems interact, problems of pluralism inevitably arise. This is because different communities-whether such communities are defined as international, national, transnational, nonstate, or epistemic-will often maintain conflicting normative commitments.

How to respond to such pluralism? This question often gets resolved in technical legal terms. Indeed, the entire field of conflict of laws (sometimes called private international law) aims to provide rules to determine what norms apply in disputes among multiple communities. These rules often devolve into formalistic questions, such as whether a particular share certificate memorializing ownership of a company or a particular Internet server is physically located within the territorial boundaries of one jurisdiction or another. Yet, the issues of how to manage pluralism must not be relegated to such technocratic inquiries. Instead, we need to recognize that the conflict of law analysis is essentially constitutional in character because it implicates the constitutive character of communities and their relationships with either an external or internal "Other."

In a recent book, Global Legal Pluralism: A Jurisprudence of Law Beyond Borders, I surveyed a wide variety of legal conflicts of this sort. ${ }^{1}$ In the book, I noted that law often operates based on a convenient fiction that nation-states exist in autonomous, territorially distinct spheres and that activities therefore fall under the legal jurisdiction of only one regime at a time. ${ }^{2}$ Thus, traditional legal rules have tied jurisdiction to territory: a state could exercise complete authority within its territorial borders and no authority beyond them. In the twentieth century, such rules were loosened, but territorial location remains the principal touchstone for assigning legal authority. ${ }^{3}$ Accordingly, if one could spatially ground a dispute, one could most likely determine the legal rule that would apply.

But consider such a system in today's world. Should the U.S. government be able to sidestep the U.S. Constitution when it houses prisoners in "offshore" detention facilities in Guantánamo Bay or elsewhere around the world? Should spatially distant corporations that create serious local harms be able to escape local legal regulation simply because they are not physically located in the jurisdiction? When the

1. Paul Schiff Berman, Global Legal Pluralism: A Jurisprudence of LaW BEYOND BORDERS (2012).

2. Id. at 4 .

3. See Paul Schiff Berman, The Globalization of Jurisdiction, 151 U. PA. L. REV. 311, 427-32 (2002). 
U.S. government seeks to shut down the computer of a hacker located in Russia, does the virus transmitted constitute an act of war or a violation of Russia's sovereignty? How can we best understand the complex relationships among international, regional, national, and subnational legal systems? Does it make sense to think that satellite transmissions, online interactions, and complex financial transactions have any territorial locus at all? And in a world where nonstate actors such as industry standard-setting bodies, nongovernmental organizations, religious institutions, ethnic groups, terrorist networks, and others exert significant normative pull, can we build a sufficiently capacious understanding of the very idea of jurisdiction to address the incredible array of overlapping authorities that are our daily reality?

Thus, a simple model that looks only to territorial delineations among official state-based legal systems is now simply untenable (if it was ever useful to begin with). Thankfully, debates about globalization have moved beyond the polarizing question of whether the nation-state is dying or not. However, one does not need to believe in the death of the nation-state to recognize that physical location can no longer be the sole criterion for conceptualizing legal authority and that nation-states must work within a framework of multiple overlapping jurisdictional assertions by state, international, and even nonstate communities. Each of these types of overlapping jurisdictional assertions creates a potentially hybrid legal space that is not easily eliminated.

These spheres of complex overlapping legal authority are, not surprisingly, sites of conflict and confusion. In response to this hybrid reality, communities might seek to "solve" such conflicts either by reimposing the primacy of territorially-based (and often nation-state-based) authority or by seeking universal harmonization. Thus, on the one hand, communities may try to seal themselves off from outside influence by retreating from the rest of the world and becoming more insular (as many religious groups seek to do), ${ }^{4}$ by building walls - either literal ${ }^{5}$ or regulatory 6 - to protect the community from outsiders, by taking measures to limit outside influence (for example,

4. See, e.g., Carol Weisbrod, The Boundaries of Utopia (1980) (discussing such communities).

5. See, e.g., Secure Fence Act of 2006, Pub. L. 109-367 (authorizing the creation of a 700-mile-long, 15-foot-high fence along the United States-Mexico border); Gwynne Dyer, World Full of Mined and Monitored Walls, GuelPH Mercury, Feb. 10, 2007, at A11, available at 2007 WLNR 2679139 (discussing border fences being built in Israel, Thailand, India, Pakistan, Uzbekistan, United Arab Emirates, and Saudi Arabia).

6. See, e.g., Ben Elgin \& Bruce Einhorn, The Great Firewall of China, BusinEssweEK ONLINE (Jan. 12, 2006), available at http://msl1.mit.edu/furdlog/docs/2006-0113_busweek_china_firewall.pdf (describing China's efforts to control internet content entering the country). 
U.S. legislation seeking to discipline judges for citing foreign or international law), ${ }^{7}$ or by falling back on territorially-based jurisdiction or choice-of-law rules. ${ }^{8}$ At the other extreme, we see calls for harmonization of norms, ${ }^{9}$ more treaties, ${ }^{10}$ the construction of international governing bodies, ${ }^{11}$ and the creation of "world law." 12

I argue that we should be wary of pinning our hopes on legal regimes that rely either on reimposing sovereignist territorial insularity or on striving for universals. Not only are such strategies sometimes normatively undesirable, but more fundamentally they simply will not be successful in many circumstances. The influence and application of foreign norms or foreign decision-making bodies may be useful and productive or may be problematic, but in any event they are inevitable and cannot be willed away by fiat.

Therefore, I suggest an alternative response to legal hybridity: we might deliberately seek to create or preserve spaces for productive

7. See, e.g., Reaffirmation of American Independence Resolution, H.R. Res. 568, 108th Cong. (2004).

8. See, e.g., Paul Schiff Berman, Conflict of Laws, Globalization, and Cosmopolitan Pluralism, 51 WAYNE L. REV. 1105 (2005) (criticizing a territorialist approach).

9. See, e.g., Jagdish Bhagwati, The Demands to Reduce Domestic Diversity Among Trading Nations, in 1 FAIR TRADE AND HARMONIZATION 9, 32-34 (Jagdish Bhagwati \& Robert E. Hudec eds., 1996) (outlining how concerns about a regulatory "race-to-the-bottom" leads to calls for international harmonization of regulatory standards).

10. See, e.g., Erin Ann O'Hara, Choice of Law for Internet Transactions: The Uneasy Case for Online Consumer Protection, 153 U. PA. L. REV. 1883 (2005) (calling for international harmonization of online consumer protection laws through the vehicle of a UN convention).

11. For an example of such thinking, consider this statement by Markus Kummer, Head Secretariat of the United Nations Working Group on Internet Governance, Int'l Telecomm. Union:

It is a positive sign that countries are discussing how to run the Internet, since it requires global solutions to its problems. . . . Governments now feel that the Internet has become so important that it should be regarded as a matter of national interest. And so they see the need for getting involved... . The governments who want to play a more active role also see a need for closer international cooperation. They feel that the United Nations is the natural system of global governance and they hold the view that a United Nations umbrella would be a prerequisite to give the necessary political legitimacy to Internet governance.

Interview with United Nations Head Secretariat of WGIG, CIRCLEID (Jul. 20, 2004 6:34 $\mathrm{AM})$, http:// www.circleid.com/posts/interview_with_united_nations_head_secretariat_of_w gig/.

12. See, e.g., Harold J. Berman, World Law: An Ecumenical Jurisprudence of the Holy Spirit, at 5, available at http://papers.ssrn.com/sol3/papers.cfm?abstract_id=666143 (Feb. 2005) ("It is obvious that there cannot be a world community without a body of world law to maintain both order and justice among its different constituents."); Harold J. Berman, World Law, 18 FORDHAM INT'L L.J. 1617-22 (1995). 
interaction among multiple, overlapping legal systems by developing procedural mechanisms, institutions, and practices that aim to manage, without eliminating, the legal pluralism we see around us. Such mechanisms, institutions, and practices can help mediate conflicts by recognizing that multiple communities may legitimately wish to assert their norms over a given act or actor, by seeking ways of reconciling competing norms, and by deferring to alternative approaches if possible. And even when a decisionmaker cannot defer to an alternative norm (because some assertions of norms are repressive, violent, and/or profoundly illiberal), procedures for managing pluralism can at least require an explanation of why deference is impossible.

The excruciatingly difficult case-by-case questions concerning how much to defer to another normative community and how much to impose the norms of one's own community are probably impossible to answer definitively. The crucial antecedent point, however, is that although people may never reach agreement on norms, they may at least acquiesce to procedural mechanisms, institutions, or practices that take pluralism seriously rather than ignoring pluralism through assertions of territorially-based power or dissolving pluralism through universalist imperatives. Processes for managing pluralism seek to preserve spaces of opportunity for contestation and local variation. Accordingly, a focus on hybridity may at times be both normatively preferable and more practical precisely because agreement on substantive norms is so difficult. In any event, the claim is only that the independent values of pluralism should always be factored into the analysis, not that they should never be trumped by other considerations.

Of course, even if pluralist institutions and processes better reflect the complexity of the world around us, this is not necessarily a reason to adopt them. Yet, we may find that the added norms, viewpoints, and participants produce better decision-making, better adherence to those decisions by participants and nonparticipants alike, and ultimately better real-world outcomes. And while this may not always be so, the essential point is that in the design of procedures, institutions, and discursive practices, these possible benefits need to be considered.

Significantly, although a pluralist approach may not offer substantive norms, it may favor procedural mechanisms, institutions, and practices that provide opportunities for plural voices. Such procedures can potentially help to channel (or even tame) normative conflict to some degree by bringing multiple actors together into a shared social space. In addition, including multiple voices may lead to better substantive outcomes because such multiplicity provides the possibility for creative alternatives that otherwise might not be heard. 
This pluralist commitment can, of course, have strong normative implications because it asks decisionmakers and institutional designers at least to consider the independent value of pluralism. For example, one might favor a hybrid domestic-international tribunal over either a fully domestic or a fully international one because it includes a more diverse range of actors, or one might favor complementarity or subsidiarity regimes because they encourage dialogue among multiple jurisdictions. Likewise, one might prefer conflict-of-law frameworks that recognize the reality of hybridity rather than arbitrarily choosing a single governing legal regime for problems implicating multiple communities. In any event, pluralism questions whether a single world public order of the sort often contemplated by both nation-state sovereignists and international law triumphalists is achievable, even assuming it were desirable.

At the same time, mechanisms, institutions, and practices of the sort I have in mind do require actors to at least be willing to take part in a common set of discursive forms. This is not as idealistic as it may at first appear. As Jeremy Waldron has argued, "[t]he difficulties of intercultural or religious-secular dialogue are often exaggerated when we talk about the incommensurability of cultural frameworks and the impossibility of conversation without a common conceptual scheme. In fact, conversation between members of different cultural and religious communities is seldom a dialogue of the deaf." 13

Nevertheless, it is certainly true that some normative systems deny even this limited goal of mutual dialogue. Such systems would correctly recognize the liberal bias within the vision of procedural pluralism I explore here, ${ }^{14}$ and they may reject the vision on that basis. For example, while most of those who either support or oppose abortion rights in the United States could be said to share a willingness-despite their differences - to engage in a common practice of constitutional adjudication, those bombing abortion clinics are not similarly willing. Accordingly, there may not be any way to accommodate such actors even within a more pluralist framework. Likewise, communities that refuse to allow the participation of particular subgroups, such as women or minorities, may be difficult to include within the pluralist vision I have in mind. Of course, these groups are undeniably important forces to

13. Jeremy Waldron, Public Reason and "Justification" in the Courtroom, 1 J.L. PHIL. \& CULTURE 107, 112 (2007).

14. This is not to say that the vision of pluralism I explore should be taken as synonymous with liberalism, though they share many attributes. For a discussion of the relationship between legal pluralism and liberalism, see Paul Schiff Berman, How Legal Pluralism Is and Is Not Distinct From Liberalism: A Reply to Denis Patterson \& Alexis Galán, 11 INT’L J. CONST. L. 801 (2013). 
recognize and take account of as a descriptive matter. But from a normative perspective, an embrace of a jurisprudence of hybridity need not commit one to a worldview free from judgment, where all positions are equivalently embraced. Thus, I argue not necessarily for undifferentiated inclusion, but for a set of procedural mechanisms, institutions, and practices that are more likely to expand the range of voices heard or considered, thereby creating more opportunities to forge a common social space than either sovereignist territorialism or universalism. ${ }^{15}$ In that sense, the vision I pursue here is at least partly indebted to the proceduralist vision of Jürgen Habermas ${ }^{16}$ and can be criticized on similar grounds. Nevertheless, we need not construct ideal dialogic contexts in order to imagine procedural mechanisms, institutional designs, and discursive practices for managing pluralism.

Finally, we can view this jurisprudence of hybridity as a form of fruitful constitutional interaction among multiple communities. Why constitutional? Because these interactions are fundamentally constitutive and because they imagine ways to structure permanent interaction with other communities. Thus, we need to start by considering (in psychological, sociological, and philosophical terms) possible ways of conceptualizing the Other. Then, we can identify procedural principles that would undergird any constitutional design that seeks to manage, without eliminating, hybridity. These two tasks are the subject of the next part of this article. In conclusion, I offer some concrete examples of such a pluralist constitutional design.

\section{Self, Other, AND the Negotiation of Difference}

How do we encounter the Other? How do we experience those who are different? Can we communicate? Can we live in parallel? Can we learn from those who are different? Can we ignore them? How do we manage the inevitable jostling that may arise? These are questions that are simultaneously psychological, sociological, political, and legal and, therefore, should be addressed on many different levels at once.

One possible response to the encounter with the Other is to focus on those attributes that make the Other not so different at all. This is the "we're all fundamentally the same" gambit we hear so often. And, interestingly, this focus on sameness can be adopted both by die-hard nationalists-who use it to insist that "our" norms (whoever the "our"

15. This focus on jurisgenerative structure, rather than on the necessary inclusion of, or deference to, all points of view, may differentiate legal pluralism as I use it here from multiculturalism.

16. See generally JÜrgEn HABERMAS, BETWEen FACTS AND NORMS: CONTRIBUTIONS to A Discourse Theory of LAW AND DEMOCRACY (William Rehg trans., 1996). 
might be) should govern all-and committed universalists, who use it to push for uniform norms operating cross-culturally throughout space and time.

In this same vein, some sociological studies of communication start from the idea that interpersonal interaction requires both parties in an encounter to believe (or at least assume) that the other is not truly other at all. ${ }^{17}$ According to this view, most associated with Alfred Schutz, ${ }^{18}$ differences in individual perspectives are overcome only if each party tacitly believes that he or she could effectively trade places with the other. As Schutz describes it, "I am able to understand other people's acts only if I can imagine that I myself would perform analogous acts if I were in the same situation."19 Thus, differences in perspective are reduced to differences in situation. Any, possibly more fundamental, differences are suppressed to facilitate dialogue.

As a result, the deliberate assuming away of the unfamiliar is seen as a constant part of everyday life. The unfamiliar is relegated to the category of "strange," and "strangeness" necessarily is placed elsewhere, somewhere other than the interaction at hand. ${ }^{20}$ Moreover, Harold Garfinkel and other ethnomethodologists have argued that individuals do not simply passively maintain these assumptions but are constantly engaged in a joint enterprise aimed at sustaining this familiarity. ${ }^{21} \mathrm{In}$ all of these studies, the emphasis is on "the human production of common worlds of meaning as the only axis on which dialogue rotates." 22

But is that all there is to the experience of the Other? Is it really imperative constantly to assume that our fellow human beings are fundamentally identical to us? After all, "[u]nder this principle, if a dialogue is to take place, strangeness as a phenomenon of everyday interaction must be considered negatively, namely, as that part of an encounter that must be constantly 'assumed away' by the

17. See generally Z. D. Gurevitch, The Other Side of Dialogue: On Making the Other Strange and the Experience of Otherness, 93 AM. J. Soc. 1179 (1988).

18. See generally Alfred Schutz, Collected Papers I: The Problem of Social REAlity (Maurice Natanson ed., 1962) [hereinafter Schutz, Problem]; Alfred Schutz, On Phenomenology AND Social RELATions (Helmut R. Wagner ed., 1970) [hereinafter SchutZ, On Phenomenology]; Alfred Schuetz, The Stranger: An Essay in Social Psychology, 49 AM. J. Soc. 499 (1944).

19. Schutz, On PhenOMENOlOGY, supra note 18, at 181.

20. Gurevitch, supra note 17, at 1180 (summarizing arguments in SCHUTZ, PROBLEM, supra note 18).

21. See, e.g., Harold Garfinkel, Studies of the Routine Grounds of Everyday Activities, 11 Soc. PROBS. 225 (1964).

22. Gurevitch, supra note 17 , at 1180 . 
participants." ${ }^{23}$ Thus, we are left with a world in which people are classified either as familiar or as strangers. Even more problematic, these studies suggest that it will be simply impossible to bridge the communication gap with those deemed strangers. Yet, as Georg Simmel noted long ago, the stranger is never truly distant, ${ }^{24}$ so there will need to be some way of bridging gaps short of assuming away strangeness altogether.

On the other hand, we might respond to such encounters with the Other by retreating to a gated community and trying to lead a hermetically-sealed existence. Here, the Other remains fully Other, and no communication is possible.

Both of these responses, when translated to law, are fundamentally jurispathic. They kill off competing interpretations by authoritatively saying that this is the law and that is not. So, either a single nation-state's norms govern or one universal law governs. Such jurispathic legal assertions may sometimes be effective, necessary, or desirable, but they are not the only ways to structure legal relations among multiple communities. Indeed, they both represent a fundamental retreat from hybridity. Yet, hybridity is difficult to escape in a world of overlapping jurisdictions and normative diversity, whereas the pluralists would say-multiple conflicting legal systems occupy the same social field. The question therefore often becomes: are there other approaches to managing pluralism? Can we come up with a more pluralist constitutional order? What are the constitutional principles we might apply?

Unlike the universalist approach, a pluralist vision does not require people to be conceptualized as fundamentally identical in order to be brought within the same normative system. Nor does a pluralist vision render outsiders irrelevant, as sovereignist territorialism does. Instead, pluralism attempts to navigate a different path altogether. A pluralist constitutional frame asks whether we can seek solutions without assuming commonality or seek harmonization while preserving the insistence on difference that contextualists rightly emphasize. In short, pluralism questions whether we are doomed either to require commonality or to essentialize difference. Are those truly the only possible approaches?

Think again of how we encounter a stranger. Do we necessarily see that stranger as fundamentally the same as we are or fundamentally different? Might not we see (and celebrate) important differences while

23. Id. at $1181-82$

24. See generally Georg Simmel, The Stranger, in The Sociology of GEORG Simmel 402 (Kurt H. Wolff ed., 1950). 
seeking ways to bridge those gaps so that we might communicate with each other and live peaceably side by side?

Perhaps we might draw from Hannah Arendt, who offers a different way of conceptualizing the encounter with the stranger. Instead of assuming commonality, she seeks, in Understanding and Politics, the quality that "makes it bearable for us to live with other people, strangers forever, in the same world, and makes it possible for them to bear with us." 25 Note that for Arendt, the task is how to "bear with" strangers, even while recognizing that they will forever be strange. ${ }^{26}$ Arendt's strategy for bearing with strangers is more than just mutual indifference and more than just toleration as well. It "involves a mental capacity appropriate for an active relation to that which is distant," 27 which Arendt locates in King Solomon's gift of the "understanding heart." 28 Understanding, according to Arendt, "is the specifically human way of being alive; for every single person needs to be reconciled to a world into which he was born a stranger and in which, to the extent of his distinct uniqueness, he always remains a stranger." ${ }^{29}$ What does "understanding" entail for Arendt? This is a bit difficult to pin down, but she makes clear that understanding is not gained through direct experience of the Other, and it is not just knowledge of the other. ${ }^{30}$ Instead, understanding starts from the individual situated apart from others. Thus, instead of "feeling your pain," understanding involves determining what aspects of the pain people feel have to do with politics and what politics can do to resolve our common dilemmas. Moreover, "[u]nderstanding can be challenged and is compelled to respond to an alternative argument or interpretation." 31 In short, understanding in Arendt's formulation looks a lot less like empathy and a lot more like judging. ${ }^{32}$

While assuming sameness leads to a universalist harmonization approach, Arendt's more distanced conception of the encounter with the stranger is akin to the pluralist vision I am pursuing as an alternative. Likewise, consider Iris Marion Young's idea of "unassimilated

25. HANNAH ARENDT, Understanding and Politics (The Difficulties of Understanding), in ESSAYS IN UNDERSTANDING: 1930-1954, at 307, 322 (Jerome Kohn ed., 1994).

26. In focusing on Arendt's idea of "bearing with strangers," I draw from the analysis in Phillip Hansen, Hannah Arendt and Bearing with Strangers, 3 CONTEMP. POL. THEORY 3 (2004).

27. Id. at 3 .

28. ARENDT, supra note 25 , at 322.

29. Id. at 308 .

30. See id. at 313 .

31. Jean Bethke Elshtain, Judging Rightly, 47 FIRST THINGs 49, 49 (1994) (reviewing ARENDT, supra note 25).

32. See ARENDT, supra note 25, at 313. 
otherness," which she posits as the relation among people in the ideal "unoppressive city." ${ }_{33}$ Young envisions ideal city life as the “"being-together' of strangers." 34 These strangers may remain strangers and continue to "experience each other as other." 35 Indeed, they do not necessarily seek an overall group identification and loyalty. Yet, they are open to "unassimilated otherness." ${ }^{6}$ They belong to various distinct groups or cultures and are constantly interacting with other groups. But, they do so without seeking either to assimilate or to reject those others. Such interactions instantiate an alternative kind of community, ${ }^{37}$ one that is never a hegemonic imposition of sameness but that nevertheless prevents different groups from ever being completely outside one another. ${ }^{38}$ In a city's public spaces, Young argues, we see glimpses of this ideal: "The city consists in a great diversity of people and groups, with a multitude of subcultures and differentiated activities and functions, whose lives and movements mingle and overlap in public spaces." 39 In this vision, there can be community without sameness, shifting affiliations without ostracism.

\section{Constitutional Principles for Managing PluRalism}

With this alternative frame in mind, here's an initial cut at translating this pluralist vision into a set of principles for constitutional design. Significantly, these principles are not derived from any overarching universal set of truths and do not require a commitment to universalism. They only require a pragmatic willingness to engage with other possible normative systems and potentially to restrain one's own jurispathic voice for the sake of forging more workable, longer-lasting relationships and harmony among multiple communities. Sometimes, of course, such deference to the Other will not be possible; constitutional

33. See Iris Marion Young, The Ideal of Community and the Politics of Difference, in FEMINISM/PostModERnism 300, 317 (Linda J. Nicholson ed., 1990) ("Our political ideal is the unoppressive city.").

34. Id. at 318.

35. $I d$.

36. Id. at 319 .

37. Young resists using the word "community" because of the "urge to unity" the term conveys but acknowledges that "[i]n the end it may be a matter of stipulation" whether one chooses to call her vision "community." Id. at 320. See also Jerry Frug, The Geography of Community, 48 STAN. L. REv. 1047, 1049 (1996) ("Unlike Young, I do not cede the term community to those who evoke the romance of togetherness.").

38. See Young, supra note 33, at 319 (positing that a group of strangers living side by side "instantiates social relations as difference in the sense of an understanding of groups and cultures that are different, with exchanging and overlapping interactions that do not issue in community, yet which prevent them from being outside of one another").

39. $I d$. 
pluralism only seeks to embed habitual practices in which deference is considered and attempted, not in which it is always implemented. Let's see what some of these constitutional principles might be.

First, a pluralist approach to managing hybridity should not attempt to erase the reality of that hybridity. Indeed, arguably the desire to "solve" hybridity problems is precisely what has made conflict of laws such a conceptually unsatisfying field for so long. Each generation seeks a new way (or often the revival of an old way) to divine an answer to what is at its root an unanswerable question: which territorially-based state community's norms should govern a dispute that, by definition, is not easily situated territorially and necessarily involves affiliations with multiple communities?

Second, a pluralist framework recognizes that normative conflict is unavoidable and so, instead of trying to erase conflict, seeks to manage it through procedural mechanisms, institutions, and practices that might at least draw the participants to the conflict into a shared social space. This approach draws on Ludwig Wittgenstein's idea that agreements are reached principally through participation in common forms of life, rather than through agreement on substance. ${ }^{40}$ Or, as the political theorist Chantal Mouffe has put it, we need to transform "enemies"-who have no common symbolic space-into "adversaries." 41 Adversaries, according to Mouffe, are "friendly enemies": friends because they "share a common symbolic space but also enemies because they want to organize this common symbolic space in a different way." ${ }^{2}$ Ideally, law-and particularly legal mechanisms for managing hybridity-can function as the sort of common symbolic space that Mouffe envisions and can therefore play a constructive role in transforming enemies into adversaries. This is akin to Young's ideal city.

Of course, Mouffe might well disagree with my application of her idea to law. Indeed, in The Democratic Paradox, she writes that "one cannot oppose, as so many liberals do, procedural and substantial justice without recognizing that procedural justice already presupposes acceptance of certain values." ${ }^{43}$ Her point is well taken; certainly my focus on procedural mechanisms, institutions, and practices necessarily limits the range of pluralism somewhat because it requires participants to accept the principles underlying the values of procedural pluralism itself. This is, to a large extent, a vision consonant with liberal

40. Ludwig Wittgenstein, Philosophical Investigations $§ 241$ (G. E. M. Anscombe trans., 3 d ed. 1967).

41. Chantal Mouffe, The Democratic Paradox 13 (2000).

42. $I d$.

43. $I d$. at 68 . 
principles, and many may reject it on that basis. Alas, there is no way to extricate oneself from this concern if one wants to have any type of functioning legal system for negotiating normative difference. Thus, I argue only that a pluralist framework is more likely to draw participants together into a common social space than a territorialist or universalist framework would. As philosopher Stuart Hampshire has argued, because normative agreement is impossible, "[f]airness and justice in procedures" are the only virtues that offer even the possibility for broader sharing. ${ }^{44}$ Accordingly, the key is to create spaces for such broader sharing, spaces for turning enemies into adversaries, without insisting on normative agreement. ${ }^{45}$

Third, to help create this sort of shared social space, procedural mechanisms, institutions, and practices for managing pluralism should encourage decisionmakers to wrestle explicitly with questions of multiple community affiliation and the effects of activities across territorial borders, rather than shunting aside normative difference. As a result, a pluralist framework invites questions that otherwise might not be asked: How are communities appropriately defined in today's world? To what degree do people act on the basis of affiliations with nonstate or supranational communities? How should the various norm-generating communities in the global system interact so as to provide opportunities for contestation and expression of difference? Such questions must be considered carefully to develop mechanisms that will take seriously the multifaceted interactions of such communities.

Thus, a pluralist conception makes no attempt to deny the multi-rooted nature of individuals within a variety of communities, both territorial and nonterritorial. Accordingly, although a pluralist conception might acknowledge the potential importance of asserting universal norms in specific circumstances, it does not require a universalist belief in a single world community. As a result, pluralism offers a promising rubric for analyzing law in a world of diverse normative voices.

Fourth, thinking in pluralist terms forces consideration of so-called conflicts values, particularly the independent benefit that may accrue when domestic judicial and regulatory decisions take into account a

44. StuART HAMPSHIRE, JUstice Is CONFLiCT 53 (2000).

45. Cf. Jeremy Waldron, Tribalism and the Myth of the Framework, in KARL POPPER: CRITICAL APPRAISALS 203, 221 (Philip Catton \& Graham Macdonald eds., 2004) ("Humans are enormously curious about each other's ideas and reasons, and, when they want to be, they are resourceful in listening to and trying to learn from one another across what appear to be barriers of cultural comprehensibility, often far beyond what philosophers and theorists of culture give them credit for."). 
broader interest in a smoothly functioning overlapping international legal order, reflecting what Justice Blackmun called "the systemic value of reciprocal tolerance and goodwill." 46 For example, U.S. courts give full faith and credit to judgments rendered in other states even if those judgments would be illegal if issued by the crediting state. ${ }^{47}$ Thus, the conflicts value of respecting an interlocking national system outweighs individual parochial interests. Such considerations should always be part of any mechanism for addressing the overlap of plural legal systems. Moreover, taking account of these sorts of systemic values should be seen as a necessary part of how communities pursue their interests in the world, not as a restraint on pursuing such interests. After all, if it is true that communities cannot exist in isolation from one another, then there is a long-term parochial benefit from not insisting on narrow parochial interest and, instead, establishing mechanisms for trying to defer to others' norms where possible.

Fifth, even a system that respects conflicts values will, of course, sometimes find a foreign law such an anathema that the law will not be enforced. Or, a local religious practice may be so contrary to state values that it will be deemed illegal. Or, creating a zone of autonomy for a particular minority group might so threaten the stability of the larger community that it cannot be countenanced. Thus, embracing pluralism in no way requires a full embrace of illiberal communities and practices or the recognition of autonomy rights for every minority group across the board. But when such "public policy" exceptions are invoked within a pluralist framework, they should be treated as unusual occasions requiring strong normative statements regarding the contours of the public policy. 48 This means that, as Robert Cover envisioned, a jurispathic act that "kills off" another community's normative

46. Société Nationale Industrielle Aérospatiale v. U.S. District Court, 482 U.S. 522, 555 (1987) (Blackmun, J., concurring in part and dissenting in part).

47. See, e.g., Estin v. Estin, 334 U.S. 541, 545-46 (1948) (stating that the full faith and credit clause "ordered submission ... even to hostile policies reflected in the judgment of another State, because the practical operation of the federal system, which the Constitution designed, demanded it”). See also Milwaukee Cnty. v. M. E. White Co., 296 U.S. 268, 277 (1935) ("In numerous cases this court has held that credit must be given to the judgment of another state, although the forum would not be required to entertain the suit on which the judgment was founded."); Fauntleroy v. Lum, 210 U.S. 230, 237 (1908) (stating that the judgment of a Missouri court was entitled to full faith and credit in Mississippi even if the Missouri judgment rested on a misapprehension of Mississippi law).

48. See, e.g., Convention on the Recognition and Enforcement of Foreign Arbitral Awards, June 10, 1958, 21 U.S.T. 2517, 330 U.N.T.S. 38 (requiring courts to enforce the judgment or arbitral award unless the agreement is null and void, inoperative, incapable of being performed, or if enforcing it would be repugnant to the public policy of the enforcing forum). 
commitment is always at least accompanied by an equally strong normative commitment. ${ }^{49}$ The key point is to make decisionmakers self-conscious about their necessary jurispathic actions. ${ }^{50}$ Only such an approach has any chance of preventing adversaries from turning into enemies.

Finally, a pluralist framework must always be understood as a middle ground between strict territorialism, on the one hand, and universalism, on the other. The key, therefore, is to try to articulate and maintain a balance between these two poles. As such, successful mechanisms, institutions, or practices will be those that simultaneously celebrate both local variation and international order and recognize the importance of preserving both multiple sites for contestation and an interlocking system of reciprocity and exchange. Of course, actually doing that in difficult cases is a Herculean and perhaps impossible task. Certainly, mutual agreement about contested normative issues is unlikely and, as discussed previously, possibly even undesirable. Thus, the challenge is to develop ways to seek mutual accommodation while keeping at least some "play" in the joints so that diversity is respected as much as possible. Such play in the joints also allows for the jurisgenerative possibilities inherent in having multiple lawmaking communities and multiple norms. ${ }^{51}$ Always, the focus is on trying to forge the sort of shared social space that Mouffe describes for transforming enemies into adversaries and Young describes as the ideal city.

Taken together, these principles provide a set of criteria for evaluating the ways in which legal systems interact. In addition, the principles could inform a community (whether state-based or not) that wishes to design mechanisms, institutions, or practices for addressing hybrid assertions of norms. Of course, such criteria are not exclusive. For example, a procedure or practice that manages pluralism well but denies certain norms of fundamental justice might be deemed problematic, regardless of its embrace of pluralism. Thus, my goal is not

49. See Robert M. Cover, The Supreme Court, 1982 Term-Foreword: Nomos and Narrative, 97 HARV. L. REV. 4, 53 (1983) (describing judges as inevitably "people of violence" because their interpretations "kill" off competing normative assertions).

50. See Judith Resnik, Living Their Legal Commitments: Paideic Communities, Courts, and Robert Cover (An Essay on Racial Segregation at Bob Jones University, Patrilineal Membership Rules, Veiling, and Jurisgenerative Practices), 17 YALE J.L. \& HuMAN. 17, 25 (2005) ("[Cover] wanted the state's actors . . . to be uncomfortable in their knowledge of their own power, respectful of the legitimacy of competing legal systems, and aware of the possibility that multiple meanings and divergent practices ought sometimes to be tolerated, even if painfully so.").

51. See Seyla Benhabib, Another Cosmopolitanism 49 (Robert Post ed., 2006) (discussing and defining "jurisgenerative processes"). 
to say that embracing pluralism always overrides other concerns. After all, as mentioned previously, many legal and quasi-legal orders are repressive and profoundly illiberal, and their norms may be resisted on those grounds. Instead, the important point is simply that pluralist considerations should always at least be part of the constitutional design, inculcating habits of mind that promote deference and restraint. Accordingly, decisionmakers should always ask: Are there other normative systems at play here? Should I restrain my jurispathic voice? Is there some other decisionmaker who might more appropriately speak to this issue? Are there ways I could develop a hybrid decisional framework that brings more voices to the table? And how can I design on-going practices, procedures, or institutional arrangements to constitutionally embed these inquiries?

\section{Constitutional Mechanisms For Managing Global Legal PluRALISM}

\section{A. Dialectical Legal Interactions}

Constitutions tend to try to demarcate clear hierarchical lines of authority among different decisionmakers. But a more pluralist constitutional design might, instead, create opportunities for dialectical legal interactions. For instance, some who study international law fail to find real "law" in the international realm because they are looking for hierarchically based commands backed by coercive power. ${ }^{52}$ In contrast, a pluralist approach understands that interactions among various tribunals and regulatory authorities are more likely to take on a dialectical quality that is neither the direct hierarchical review traditionally undertaken by appellate courts, nor simply the dialogue that often occurs under the doctrine of comity. ${ }^{53}$ Thus, we may see treaty-based courts exert an important influence even as national courts retain formal independence, much as U.S. federal courts exercising habeas corpus jurisdiction may well influence state court interpretations of U.S. constitutional norms in criminal cases. ${ }^{54}$ In turn, the decisions of national courts may also come to influence international

52. See, e.g., Jack L. Goldsmith \& Eric A. Posner, The Limits of International LAW (2005).

53. See Robert B. Ahdieh, Between Dialogue and Decree: International Review of National Courts, 79 N.Y.U. L. REV. 2029 (2004), for a detailed analysis of such dialectical regulation.

54. See id. at $2034,2068$. 
tribunals. This dialectical and iterative process ${ }^{55}$ can exist without an official hierarchical relationship based on coercive power.

Three examples illustrate the point. First, we might think of the relationship between free-trade panels and nation-state courts. For example, in Loewen Group v. United States, a North American Free Trade Agreement (NAFTA) tribunal reviewed the procedures of the Mississippi courts concerning contract and antitrust claims brought by a local entity against a Canadian corporation. ${ }^{56}$ The tribunal criticized the trial as "so flawed that it constituted a miscarriage of justice amounting to a manifest injustice as that expression is understood in international law." 57 In addition, the tribunal criticized the total award, including $\$ 400$ million in punitive damages issued by the trial court as "grossly disproportionate" to the damage actually suffered. ${ }^{58}$ While in the end the NAFTA panel refrained (on standing grounds) from assessing damages against the United States, ${ }^{59}$ there is little reason to think that liability in similar situations will not be imposed in the future.

Thus, the relevant question for our purposes is how will a domestic court, faced with a multinational dispute in the future, respond both to the NAFTA precedents already in place and the threat of possible NAFTA panel review. Although these NAFTA panels lack formal authority over the domestic courts they review, they do have the power to assess damages against federal authorities for violations of the trade agreement, even if those violations occurred in the context of a domestic court judgment. Thus, we see plural sources of normative authority: the domestic court that issues an initial judgment; the NAFTA tribunal that reviews this judgment for fidelity with the principles of the treaty; and the federal authorities who, in response to pressure from the NAFTA tribunal, may in turn put pressure on the domestic court. Robert Ahdieh has argued that, given these realities, we are likely to see, over time, a dialectical relationship form between the domestic and international tribunals, in which those courts pay attention to each other's interpretations and, while not literally bound by each other's decisions, develop a joint jurisprudence partly in tandem and partly in tension with each other. ${ }^{60}$

55. See BENHABIB, supra note 57, at 48 ("Every iteration involves making sense of an authoritative original in a new and different context. The antecedent thereby is reposited and resignified via subsequent usages and references.").

56. Loewen Group, Inc. v. United States, ICSID Case No. ARB(AF)/98/3, Award, ๆ 1 , 3, 42, 46 (June 26, 2003), 7 ICSID Rep. 442 (2005).

57. Id. ๆ 54.

58. See id. ๆ 101, 113.

59. See id. ๆ 238-240.

60. See Ahdieh, supra note 53, at 2079-82. 
To see how the sort of dialectical relationship Ahdieh posits might actually play out, consider interactions between the European Court of Human Rights (ECHR) and the constitutional courts of European Member States. Here, the relationship may seem more hierarchical because, over the past several decades, the ECHR has increasingly come to seem like a supranational constitutional court, and its authority as ultimate arbiter of European human rights disputes has largely been accepted. ${ }^{61}$ Yet, even in this context there appears to be room for hybridity. As Nico Krisch has documented, domestic courts occasionally refuse to follow ECHR judgments, asserting fundamental principles embedded in their own constitutional order and, in general, claiming the power to determine the ultimate limits to be placed on the authority of the ECHR. ${ }^{2}$ Typical of this dialectical relationship is the statement by the German Constitutional Court that ECHR judgments have to be "taken into account" by German courts but may have to be "integrated" or adapted to fit the domestic legal system. ${ }^{63}$ Moreover, the German Court has gone so far as to say that ECHR decisions must be disregarded altogether if they are "contrary to German constitutional provisions." 64

Yet, although such statements make it sound as if conflict between the ECHR and domestic courts is the norm, the reality has actually been quite harmonious. As Krisch points out, "despite national courts' insistence on their final authority, the normal, day-to-day operation of the relationship with the [ECHR] has lately been highly cooperative, and friction has been rare." 65 The picture that emerges is one in which domestic courts and the ECHR engage in a series of both informal and interpretive mutual accommodation strategies to maintain a balance between uniformity and dissention. Likewise, as Lisa Conant has observed, nation-state courts have sought to "contain" the impact of European Court of Justice (ECJ) decisions on national legal orders, even while formally accepting both the supremacy of EU law and the ECJ's role in authoritatively interpreting that law. ${ }^{66}$ These sorts of dialectical relationships, forged and developed over many years, may well reflect the path yet to be taken by the NAFTA tribunals and domestic courts,

61. See generally Nico Krisch, The Open Architecture of European Human Rights Law, 71 MOD. L. REV. 183 (2008) (discussing the evolution of the European human rights regime while tracing the interaction of the European Court of Human Rights with domestic courts in the European Union).

62. See generally id.

63. Id. at 196.

64. Id. at 196-97.

65. Id. at 197.

66. See Lisa Conant, Justice Contained: LAW AND Politics In the EURopean Union 3 (2002). 
as well as the many other intersystemic interactions at play in the world today.

Finally, consider the Canadian Constitution, which explicitly contemplates a dialectical interaction between national courts and provincial legislatures concerning constitutional interpretation. Section 33's so-called "notwithstanding" clause permits Parliament or a provincial legislature to authorize the operation of a law for a five-year period, even after it has been declared invalid by a court. ${ }^{67}$ As with the ECHR example, this provision potentially has a disciplining effect on the court and encourages a more nuanced iterative process in working out constitutional norms. It is true of course that the notwithstanding clause, though often invoked rhetorically, has only rarely actually been used by provincial governments to continue a judicially invalidated law. ${ }^{68}$ Yet, this relative infrequency of use may not be evidence of a failed constitutional innovation. Instead, it may indicate just the opposite: that the various institutional actors have sufficiently internalized this mechanism for managing hybridity such that, as in the ECHR example, the precipice is rarely reached. ${ }^{69}$

In contrast to the dialectical interplay contemplated by the "notwithstanding clause," the U.S. Supreme Court has, on multiple occasions, interpreted the U.S. Constitution to contain an implicit foreign affairs preemption doctrine that cuts off such interplay. ${ }^{70}$ For

67. See Canadian Charter of Rights and Freedoms, Part I of the Constitution Act, 1982, being Schedule B to the Canada Act, 1982, c. 11, § 33 (U.K.).

68. For example, the Quebec Parliament overrode the Canadian Supreme Court's invalidation of provisions of a language law. See Ford v. Quebec, [1988] 2 S.C.R. 712 (Can.). However, outside Quebec the notwithstanding clause has never been used to overturn a judicial decision. See James Allan \& Grant Huscroft, Constitutional Rights Coming Home to Roost? Rights Internationalism in American Courts, 43 SAN DIEGO L. REV. 1, 21 (2006). In addition, according to one account, the clause has been disavowed by successive prime ministers because "[i]ts use has come to be seen as undermining the Charter, in part because judicial decisions interpreting the Charter have come to be seen as synonymous with the Charter itself." Id. at 20.

69. On the other hand, it is possible that "the notwithstanding clause frees Canadian courts to be less deferential to elected legislatures than they otherwise would have been in the absence of such a clause, because it allows judges to act on the basis that their decisions are not final." Allan \& Huscroft, supra note 68, at 21-22 (emphasis added). In any event, the important point for our purposes is that the clause is structured as a mechanism for managing the hybridity of multiple communities within a federal system. See Jennifer Nedelsky, Reconceiving Rights and Constitutionalism, 7 J. HuM. RTS. 139, 147-48 (2008), for an account supporting the approach of the notwithstanding clause from the perspective of political theory.

70. See, e.g., American Ins. Ass'n v. Garamendi, 539 U.S. 396 (2003) (striking down California law requiring insurance companies doing business in California to disclose any business activities in Europe during the Nazi Holocaust); Crosby v. Nat'l Foreign Trade Council, 530 U.S. 363 (2000) (prohibiting Massachusetts from banning state expenditures 
example, the Court has refused to allow localities to take actions that were deemed to encroach upon the exclusive national prerogative to conduct foreign affairs. Yet, one might think that "[in our] democratic federation . . . local efforts to effectuate protection of rights have a presumptive validity" authorized by the commitments to multiple voices protected in a federal system..$^{71}$ At the very least, courts should carefully interrogate the claimed justification for preemption to ensure that the local action at issue poses a real, rather than conjectural, threat to the federal government's conduct. ${ }^{72}$ After all, pluralism is built into the structure of federalism, and so actions of localities to import international or foreign norms or signal solidarity with them should not easily be displaced.

Indeed, at times we can see the explicit creation of dialectical legal regimes to manage federalist interactions. For example, take California's efforts to impose more stringent automobile fuel efficiency standards than the federal government's standards. At first glance, this might seem to be simply a direct state challenge to federal authority. However, the entire regime under which California can apply for a waiver to impose stricter standards is itself a creature of federal law because it is the Clean Air Act that grants California the special status in regulating automobile emissions ${ }^{73}$ and that arguably has contributed to California's regulatory leadership in this area. ${ }^{74}$ Similarly, the 1990 amendments to the Clean Air Act established a formal mechanism whereby northeastern states were granted the ability to cooperate in the control of ozone, but the Environmental Protection Agency (EPA) was given the power to approve or disapprove any recommendations the consortium might have. ${ }^{75}$

on goods and services from any person that had been in business with Burma); Zschernig v. Miller, 389 U.S. 429 (1968) (striking down Oregon statute that had the effect of preventing a resident of East Germany from inheriting property probated in the state). See also Judith Resnik, Foreign as Domestic Affairs: Rethinking Horizontal Federalism and Foreign Affairs Preemption in Light of Translocal Internationalism, 57 EMORY L.J. 31 (2007), for a discussion of these cases.

71. Resnik, supra note 70 , at 85.

72. See id. at 87 (“JJ]udges ought to adopt a posture of non-encroachment by insisting on exacting evidence of particular and specific imminent harms before invalidating actions by localities or by states as those entities determine their own expenditures of funds and rules.”).

73. See 42 U.S.C. $\S 7543(\mathrm{e})(2)(\mathrm{A})$ (2006).

74. See Ann E. Carlson, Iterative Federalism and Climate Change, 103 Nw. U. L. REv. 1097, 1109 (2009) ("California's leadership on climate change issues is not merely the product of state leadership. California's climate change regulations are a direct result of federal law, which has played a central role both in allowing the state to regulate and in demanding stricter regulation of air pollution.”).

75. See 42 U.S.C. $\S 7511$ c(a). 
Significantly, these provisions, both of which explicitly create formalized dialectical (or multiscalar) relations between state and federal authority, may be preferable to a regime that granted either the states or the federal government sole authority. ${ }^{76}$ As Ann Carlson argues, the federal statutes have, as an initial matter, tended to encourage the states to ratchet up their environmental protection beyond what they otherwise might have done. 77 However, the dialectical scheme has gone further and actually encouraged the deputized states to become leaders on environmental compliance. Moreover, by granting such authority to only one state or to a small group of states, the dialectical scheme reaps the benefits of permitting a greater field for experimentation than a top-down solution would ordinarily provide, while at the same time achieving greater national uniformity than would occur if each state were free to go its own way. Thus, the pluralist approach of these provisions walks a middle ground between fully decentralized and fully centralized power and arguably achieves a better outcome than either.

Likewise, the Sudan Accountability and Divestment Act of 2007 is a federal statute that authorizes states to divest from companies doing business in Sudan, but only under certain conditions and in limited ways, and only until the President certifies that the human rights abuses committed by Sudan have eased. ${ }^{78}$ Again, the federal restrictions address concerns about national uniformity in foreign affairs, but the Act does not embrace the jurispathic doctrine of foreign affairs preemption, under which the U.S. Supreme Court altogether foreclosed Massachusetts's efforts to divest from companies doing business in Burma. ${ }^{79}$ Instead, the pluralist approach of the statute provides a port of entry for states to contribute to the formulation of national foreign policy while guarding against complete devolution of foreign affairs power. As Perry Bechky has observed:

[S]tate divestment may call attention to an under-attended concern, influence societal attitudes about that concern, and build domestic political support for a more vigorous national response thereto. Congress

76. See generally Hari M. Osofsky, The Future of Environmental Law and Complexities of Scale: Federalism Experiments with Climate Change Under the Clean Air Act, 32 WASH. U. J.L. \& POL'Y 79 (2010) (suggesting ways for these multiscalar approaches to evolve in light of changing environmental law demands).

77. See Carlson, supra note 74, at 1100-01.

78. See Sudan Accountability and Divestment Act of 2007, Pub. L. No. 110-174, 121 Stat. 2516.

79. See Crosby v. Nat'l Foreign Trade Council, 530 U.S. 363 (2000). 
may reasonably conclude that it wishes to hear state speech about Darfur as it continually reassesses the degree of priority to afford Darfur amongst the many concerns competing for Congressional attention. ${ }^{80}$

Accordingly, the statutory scheme provides greater opportunity for intersystemic dialogue, public debate, and creative norm generation by multiple actors than if either a localist or nationalist solution had fully triumphed.

These examples all involve dialectical interactions between formal state or international legal institutions. However, the same dialectical interactions are possible with regard to nonstate normative standards. For example, the decisions of arbitral panels may, over time, exert influence on the decisions of more formal state or international bodies, and vice versa. In a different context, states may incorporate or adapt standards of conduct that are part of accreditation schemes promulgated by nongovernmental organizations (NGOs) or industry groups. ${ }^{81}$ And more broadly, we might see the creation of monitoring schemes in general as a kind of pluralist approach because instead of dictating rules, such monitoring generates oversight and publicity that can instigate change without a formal hierarchical relationship or coercive enforcement.

\section{B. Margins of Appreciation}

One of the interpretive mechanisms employed by the ECHR to maintain space for local variation is the oft-discussed "margin of appreciation" doctrine. ${ }^{82}$ Unlike the dialectical legal encounter between the ECHR and the German Constitutional Court, the margin of appreciation doctrine is an explicit interpretive device employed by the ECHR to give play to local variation. The idea here is to strike a balance between deferring to national courts and legislators, on the one hand, and maintaining "European supervision" that "empower[s the ECHR] to

80. Perry S. Bechky, Darfur, Divestment, and Dialogue, 30 U. PA. J. INT’’ L. 823, 826 (2009).

81. See, e.g., Jody Freeman, The Private Role in Public Governance, 75 N.Y.U. L. REV. 543, 618-19 (2000) (describing government incorporation of accreditation standards on health maintenance organizations (HMOs) first promulgated by nongovernmental entities). See also Laura A. Dickinson, Outsourcing War and Peace: Preserving Public VAlues IN A World of PRIVATIZED Foreign AFFAIRS 92-95 (2011) (proposing such an accreditation scheme for disciplining private military contractors).

82. See generally Laurence R. Helfer \& Anne-Marie Slaughter, Toward a Theory of Effective Supranational Adjudication, 107 YALE L.J. 273, 316-17 (1997), for a particular useful, succinct summary. My discussion here largely tracks theirs. 
give the final ruling" on whether a challenged practice is compatible with the European Convention on Human Rights, on the other. ${ }^{83}$ Thus, the margin of appreciation allows domestic polities some room to maneuver in implementing ECHR decisions in order to accommodate local variation. How big that margin is depends on a number of factors, including the degree of consensus among the Member States. For example, in a case involving parental rights of transsexuals, the ECHR noted that because there was as yet no common European standard, and "generally speaking, the law appears to be in a transitional stage, the respondent State must be afforded a wide margin of appreciation." 84

Affording this sort of variable margin of appreciation usefully accommodates a limited range of pluralism. It does not permit domestic courts to ignore fully the supranational pronouncement (though, as discussed previously, domestic courts have sometimes asserted greater independence). Nevertheless, it does allow space for local variation, particularly when the law is in transition or when no consensus exists among Member States on a given issue. Moreover, by framing the inquiry as one of local consensus, the margin of appreciation doctrine disciplines the ECHR and forces it to move incrementally, pushing toward consensus without running too far ahead of it.

Finally, the margin of appreciation functions as a signaling mechanism, through which "the ECHR is able to identify potentially problematic practices for the contracting states before they actually become violations, thereby permitting the states to anticipate that their laws may one day be called into question." 85 And of course, there is reverse signaling as well, because domestic states, by their societal evolution away from consensus, effectively maintain space for local variation. As Laurence Helfer and Anne-Marie Slaughter have observed, "The conjunction of the margin of appreciation doctrine and the consensus inquiry thus permits the ECHR to link its decisions to the

83. Sunday Times v. United Kingdom, 2 Eur. H.R. Rep. 245, 276 (1979).

84. X v. United Kingdom, App. No. 21830/93, 24 Eur. H.R. Rep. 143, 144 (1997). See also Otto-Preminger Inst. v. Austria, App. No. 13470/87, 19 Eur. H.R. Rep. 34, 58 (1994) (finding that the lack of a uniform European conception of rights to freedom of expression "directed against the religious feelings of others" dictates a wider margin of appreciation).

85. Helfer \& Slaughter, supra note 82, at 317. See also Laurence R. Helfer, Consensus, Coherence and the European Convention on Human Rights, 26 CORNELL INT'L L.J. 133, 141 (1993). See J. G. Merrills, The Development of International LaW by the EUROPEAN COURT OF HUMAN RIGHTS 81 (2d ed. 1993) (interpreting the ECHR's statement in Rees v. United Kingdom, App. No. 9532/81, 9 Eur. H.R. Rep. 56, 68 (1986), that " [t]he need for appropriate legal measures [to protect transsexuals] should therefore be kept under review having regard particularly to scientific and societal developments"' as a "strong hint that while British practice currently satisfied [the Convention], the Court's duty to interpret the Convention as a living instrument may lead it to a different conclusion in the future"), for an example of this type of signaling. 
pace of change of domestic law, acknowledging the political sovereignty of respondent states while legitimizing its own decisions against them." 86 A similar sort of interaction could be established by a constitutional court adopting some form of the classic concept versus conception distinction ${ }^{87}$ with regard to the adoption of norms by other actors. Thus, an entity such as the ECHR could, for example, articulate a particular concept of rights while recognizing that the way this right is implemented is subject to various alternative conceptions.

Other legal regimes could also usefully adopt margins of appreciation. For example, the controversial agreement on Trade-Related Aspects of Intellectual Property Rights could be interpreted to incorporate a margin of appreciation. Such a flexible approach might allow developing countries more leeway in trying to make sure that access to knowledge in their countries is not unduly thwarted by stringent intellectual property protection.

\section{Subsidiary Schemes}

Subsidiarity is another mechanism for managing the interactions among different legal or quasi-legal authorities. The Catholic Church first developed subsidiarity as an ordering principle designed to prevent so-called higher levels of authority from interfering unduly with the "internal life of a community." 88 But, unlike a constitutional order based on nation-state sovereignty, a subsidiarity regime does not pose an outright bar to governance at a "higher," supranational level of authority. But, it does not offer a blank check either. The idea is to foster careful and repeated consideration of other potential lawmaking communities. Thus, "at its core the principle of subsidiarity requires any infringements of the autonomy of the local level by means of pre-emptive norms enacted on the higher level to be justified by good

86. Helfer \& Slaughter, supra note 82 , at 317.

87. See, e.g., RONALD DWORKIN, LAW'S EMPIRE 71 (1986) (discussing the difference between "concept" and "conception" as "a contrast between levels of abstraction at which the interpretation of the practice can be studied").

88. See Catechism of the Catholic Church 9 1883, VATICAN.VA, http://www.vatican.va/ archive/ENG0015/_P6G.HTM (last visited Mar. 30, 2013) (quoting John Paul II, Centesimus Annus I 48 (May 1, 1991), available at http://www.vatican.va/holy_father /john_paul_ii/encyclicals/documents/hf_jp-ii_enc_01051991_centesimus-annus_en.html\#-

2S) ("[A] community of a higher order should not interfere in the internal life of a community of a lower order, depriving the latter of its functions, but rather should support it in case of need and help to co-ordinate its activity with the activities of the rest of society, always with a view to the common good."). 
reasons." 89 Accordingly, it is not enough for a supranational governance rule simply to be a good idea; the supranational lawmaking community also must consider whether the rule is one that is appropriately enacted at the supranational level, given contrary local policies.

For example, consider the case of a higher-level authority that enacts an emissions cap to combat global climate change but runs up against a lower-level authority that performed its own cost-benefit analysis and determined that it was better for the local economy not to create such a stringent restriction. ${ }^{90}$ Here, the collective action problems inherent in the lower-level authority's parochial cost-benefit analysis would probably justify intervention at the higher level. In contrast, a higher-level rule limiting nicotine consumption might not override a more permissive local rule because the locality can plausibly decide it wants to bear the higher health care costs or other consequences that might result.

As with all mechanisms for managing hybridity, the line-drawing problems are potentially difficult and often politically contested, but even the habits of mind generated by thinking in terms of subsidiarity can help ensure that lawmaking communities at least take into account other potentially relevant lawmaking communities. ${ }^{91}$ Moreover, subsidiarity can help "local populations . . . better preserve their sense of social and cultural identity" 92 while still allowing for the possibility that higher-level governmental authority might sometimes be

89. Mattias Kumm, The Legitimacy of International Law: A Constitutionalist Framework of Analysis, 15 EUR. J. INT'L L. 907, 921 (2004).

90. See $i d$. at 923-24, for a similar hypothetical example.

91. I realize that my discussion of subsidiarity has a functionalist cast and therefore may seem to deemphasize other concerns, such as democratic legitimacy or the nation-state's claims to loyalty as against supranational institutions. See, e.g., Peter L. Lindseth, Democratic Legitimacy and the Administrative Character of Supranationalism: The Example of the European Community, 99 CoLuM. L. REV. 628, 669 (1999) (arguing that a functionalist approach "is clearly inadequate to understanding the full import of the subsidiarity principle” because it tends to ignore important issues of legitimacy); Paul D. Marquardt, Subsidiarity and Sovereignty in the European Union, 18 FoRDHAM INT'L L.J. 616,618 (1994) ("[T]he underlying logic of subsidiarity reduces the claim of rightful governance to a technocratic question of functional efficiency that will eventually undercut the nation-state's claims to loyalty."). However, the sort of dialogue that mechanisms for managing hybridity encourage need not be "technocratic" and can in fact engage with precisely the questions of legitimacy and community ties that critics want. Thus, I argue only for mechanisms that enhance dialogue; I do not circumscribe the content of that dialogue. Nevertheless, to the extent that critics of a functionalist account of subsidiarity are trying to raise a sovereigntist objection to supranationalism in general, the pluralist framework I pursue here clearly rejects such a position as both normatively undesirable and impractical. See George A. Bermann, Taking Subsidiarity Seriously: Federalism in the European Community and the United States, 94 COLUM. L. REV. 331, 341 (1994).

92. See Bermann, supra note 91, at 341. 
necessary. Finally, even though a subsidiarity regime sets the default in favor of local decisions, requiring articulated justifications to override the presumption, subsidiarity-related concerns can sometimes actually strengthen the perceived legitimacy of the higher-level authority. This is because, when the higher authority does override local regulation, it presumably does so only after carefully considering local practices and only after articulating reasons to justify such an override..$^{93}$

Accordingly, the institutional processes of subsidiarity aim to ensure dialogue among multiple legal communities, leading ideally to increased acceptance of each. Not surprisingly, subsidiarity has been proposed as a more general model for international law as well. ${ }^{94}$ Indeed, the complementarity regime of the International Criminal Court-whereby the Court only takes jurisdiction if the local state is unwilling or unable to investigate - can be seen as a form of subsidiarity scheme.

\section{Hybrid Participation Arrangements}

Sometimes hybridity can be addressed not so much through the relationships among multiple communities and their decisionmakers as through hybridizing the decision-making body or process itself. For example, from 1190 until 1870, English law used the so-called mixed jury, or jury de medietate linguae, with members of two different communities sitting side by side to settle disputes when people from the two communities came into conflict. ${ }^{95}$ Sir Edward Coke attributed this practice "to the Saxons, for whom 'twelve men versed in the law, six English and an equal number of Welsh, dispense justice to the English and Welsh."'96 Regional differences, however, were not the only type of community variation recognized in the mixed-jury custom. Mixed juries were also used in disputes between Jews and Christians, ${ }^{97}$ city and

93. See Kumm, supra note 89, at 922 ("If there are good reasons for deciding an issue on the international level, because the concerns addressed are concerns best addressed by a larger community, then the international level enjoys greater jurisdictional legitimacy.").

94. See, e.g., id. at 921-22.

95. Deborah A. Ramirez, The Mixed Jury and the Ancient Custom of Trial by Jury De Medietate Linguae: A History and a Proposal for Change, 74 B.U. L. REV. 777, 781 (1994); see also MARIANNE CONSTABLE, THE LAW OF THE OTHER 7-8 (1994) (explaining the practice of mixed juries in early England).

96. Constable, supra note 95, at 17 (referencing SIR EDWARD CoKe, THE FIRST PART OF THE INSTITUTES OF THE LAWES OF ENGLAND § 234 (1628)).

97. See id. at 18-21 (noting that half-Jewish, half-Christian juries heard suits between Jews and non-Jews in England during the twelfth and thirteenth centuries); Ramirez, supra note 95, at 783-84 (arguing that mixed juries originated in part from the king's desire to protect Jewish capital, which was subject to high assessments and escheatment to the Crown, rather than lose it to Christians in an unfair trial). 
country dwellers, ${ }^{98}$ and merchants and nonmerchants. ${ }^{99}$ In the United States, the custom of mixed juries was imported from England and used in disputes between settlers and indigenous people, ${ }^{100}$ as well as in other interjurisdictional disputes at least through the beginning of the twentieth century. ${ }^{101}$ Karl Llewellyn's proposal that merchant experts sit as a tribunal to hear commercial disputes relies on a similar idea that specialized communities may possess relevant knowledge or background that should be called upon in rendering just verdicts. ${ }^{102}$

The principles underlying mixed juries can still be found today. Indeed, the line of U.S. Supreme Court decisions involving peremptory challenges of jurors, though framed in terms of the individual right to serve on a jury, could be seen as responding in part to the broader idea that jury panels should reflect both racial and gender diversity. ${ }^{103}$ Indeed, research indicates that racially mixed juries tend to deliberate longer, consider more facts, raise more questions, and discuss more racial issues than all-white juries. ${ }^{104}$ In addition, racially mixed juries make fewer factual errors than single-race juries, and when factual inaccuracies do arise, they are more likely to be corrected in racially mixed juries than in single-race juries. ${ }^{105}$

98. See CONSTABLE, supra note 95, at 17 (recounting an action involving a country dweller in twelfth-century London that required that at least one of the jurors be of "the county in which the foreigner dwells").

99. See id. at 23-25 (exploring the evolution of "mixed merchant juries" in early England); Ramirez, supra note 95, at 784-86 (recognizing the king's regard for foreign merchants, which prompted the use of mixed juries in order to promote a "perception of fairness" to outsiders and attract their capital and goods).

100. See Katherine A. Hermes, Jurisdiction in the Colonial Northeast: Algonquian, English and French Governance, 43 AM. J. LEGAL HIST. 52, 64-65 (1999) (discussing the implementation of a mixed-jury system in colonial Pennsylvania, Rhode Island, and Massachusetts).

101. See Ramirez, supra note 95, at 790 (noting that "[a]t various times between 1674 and 1911, Kentucky, Maryland, Massachusetts, Pennsylvania, New York, Virginia, and South Carolina each provided for mixed juries").

102. See Zipporah Batshaw Wiseman, The Limits of Vision: Karl Llewellyn and the Merchant Rules, 100 HARV. L. REV. 465, 512-15 (1987) (describing Llewellyn's merchant tribunal proposal).

103. See Batson v. Kentucky, 476 U.S. 79, 89 (1986) (ruling that prosecutors may not challenge jurors solely on the basis of race); J.E.B. v. Alabama, 511 U.S. 127, 130-31 (1994) (extending Batson to peremptory challenges based on gender).

104. Samuel R. Sommers \& Phoebe C. Ellsworth, How Much Do We Really Know About Race and Juries? A Review of Social Science Theory and Research, 78 CHI.-KENT L. REV. 997, 1028 (2003).

105. See id.; Hiroshi Fukurai, Social De-Construction of Race and Affirmative Action in Jury Selection, 11 LA RAZA L.J. 17, 20 (1999) ("Jury research shows that racially heterogeneous juries are more likely than single race juries to enhance the quality of deliberations. A number of empirical studies... show that racially mixed juries minimize the distorting risk of bias."). 
In the human rights arena, hybrid domestic/international courts maintain the tradition of the mixed jury. ${ }^{106}$ Such hybrid courts have been employed in transitional justice settings in Kosovo, East Timor, Sierra Leone, and Cambodia. In these courts, domestic judges-ideally drawn from the multiple political, racial, or ethnic groups involved in the larger geopolitical conflict-sit alongside international judges, and domestic and international lawyers also work together to prosecute the cases. ${ }^{107}$

As Stephen Krasner has theorized, the sort of "shared sovereignty"108 reflected in the hybrid court structure can be particularly important when domestic institutions are weak. He argues that shared sovereignty can "gird new political structures with more expertise, better-crafted policies, and guarantees against abuses of power." 109 Following this logic, the Dayton Accords effectively made the Bosnian Constitutional Court a hybrid court, authorizing the president of the European Court of Human Rights to appoint three non-Bosnian judges to the nine-member court. ${ }^{110}$ A different kind of hybrid is the Israeli Supreme Court, which has, since its inception, customarily had at least one member who is an expert in Jewish law.111

We can also see hybrid arrangements outside the judicial context. For example, in the oil pipeline agreement between Chad and the World Bank, the two parties share control and governance of the project. ${ }^{112}$ As a condition for its participation, the World Bank insisted on a revenue management plan aimed at ensuring that the proceeds of oil development would be used for socioeconomic development. ${ }^{113}$ To that end, the plan contains important limitations on how the expected oil

106. See, e.g., Laura A. Dickinson, The Promise of Hybrid Courts, 97 AM. J. INT'L L. 295 (2003) (discussing hybrid courts generally and their attempts to provide mixed panels of judges to hear cases).

107. See id. at 295.

108. Stephen D. Krasner, Building Democracy After Conflict: The Case for Shared Sovereignty, 16 J. DEMOCRACY 69, 76 (2005) ("Shared sovereignty involves the creation of institutions for governing specific issue areas within a state-areas over which external and internal actors voluntarily share authority.”).

109. Id. at 70 .

110. See General Framework Agreement for Peace in Bosnia and Herzegovina with Annexes, annex 4, art. VI, ๆ 1(a), Dec. 14, 1995, 35 I.L.M. 75.

111. See, e.g., Donna E. Arzt, Growing a Constitution: Reconciling Liberty and Community in Israel and the United States, 19 LAW \& SOC. INQUIRY 253, 257 (1994).

112. See Emeka Duruigbo, The World Bank, Multinational Oil Corporations, and the Resource Curse in Africa, 26 U. PA. J. INT'L ECON. L. 1, 38-46 (2005), for a useful description of the terms of the project.

113. See id. at 40 . 
revenue can be invested and spent.114 In addition, oversight of the revenue plan is shared. Both the World Bank and the government of Chad must approve the annual expenditure of revenues, and there is a nine-member oversight committee, seven of whom represent the government while two represent civil society. ${ }^{115}$ The committee annually publishes a review of operations, and those operations are subject to external audit. ${ }^{116}$ Finally, the World Bank's International Advisory Group and Inspection Panel retain oversight power over the entire venture. ${ }^{117}$ Whether such measures will result in effective hybrid governance remains to be seen. But significantly, most of the criticisms of the plan thus far tend to focus on the particular terms of the shared sovereignty arrangement, not the hybrid structure itself. ${ }^{118}$

\section{E. Jurisdictional Redundancies}

Many of the legal conundrums of a hybrid world arise because of jurisdictional redundancy. That is because multiple legal communities frequently seek to assert jurisdiction over the same act or actor. Yet, while this jurisdictional overlap is frequently viewed as a problem because it potentially creates conflicting obligations and uncertainty, we might also view jurisdictional redundancy as a necessary adaptive feature of a multivariate, pluralist legal system. Indeed, jurisdictional redundancy may itself be thought of as a mechanism for managing pluralism because the existence of overlapping jurisdictional claims often leads to a nuanced negotiation-either explicit or implicit-between or among the various communities making those claims.

114. See id. at 41-42 ("In the course of the first ten years of production, that is, between 2004 and 2013, income taxes will constitute sixteen percent of total revenues to Chad and the rest will come from royalties and dividends. The government is given discretion on how to spend the revenues from income taxes subject to the limitation that they be used for general development purposes. The government has less liberty when it comes to royalties and dividends. A Special Revenue Account is created in which they would be deposited. A distribution formula has also been specified. Ten percent of the money will be kept in international financial institutions as a fund for future generations. Eighty-five percent of the remaining ninety percent will be deposited in local commercial banks and is dedicated to the financing of programs in five important sectors namely, education, health and social services, rural development, infrastructure, and environment and water resources. The remaining fifteen percent would be devoted to the development of the oilproducing Doba region.").

115. Id. at 42 .

116. Id.

117. $I d$.

118. See $i d$. at $43-46$, for a summary of criticisms. 
In focusing on the pluralist opportunities inherent in jurisdictional redundancy, I echo the insights of Robert Cover in his article, The Uses of Jurisdictional Redundancy: Interest, Ideology, and Innovation. Although his essay was focused particularly on the variety of "official" law pronouncers in the U.S. federal system, Cover identified some of the benefits that accrue from having multiple overlapping jurisdictional assertions, regardless of the context. Such benefits include a greater possibility for error correction, a more robust field for norm articulation, and a larger space for creative innovation. ${ }^{119}$ And though Cover acknowledged that it might seem perverse "to seek out a messy and indeterminate end to conflicts which may be tied neatly together by a single authoritative verdict," he nevertheless argued that we should "embrace" a system "that permits the tensions and conflicts of the social order" to be played out in the jurisdictional structure of the system. ${ }^{120}$ Thus, Cover's pluralism, though here focused on U.S. federalism, can be said to include the creative possibilities inherent in multiple overlapping jurisdictions asserted by both state and nonstate entities in whatever context they arise.

More recently, Judith Resnik has noted the "multiple ports of entry" that a federalist system creates ${ }^{121}$ and has argued that what constitutes the appropriate spheres for "local," "national," and "international" regulation and adjudication changes over time and should not be essentialized. ${ }^{122}$ Not surprisingly, other commentators have at times advocated what amounts to a federalist approach to national/supranational relations.

\section{CONCLUSION}

Once we take Global Legal Pluralism as our framework for analysis, we are better able to imagine procedural mechanisms, institutional designs, and discursive practices that are better suited to a reality of legal hybrids and overlaps. These principles can be thought of as constitutional because they address the fundamental constitutive terms under which multiple communities interact. In this essay, I have

119. See id.

120. Id. at 682 .

121. See Judith Resnik, Law's Migration: American Exceptionalism, Silent Dialogues, and Federalism's Multiple Ports of Entry, 115 YALE L.J. 1564 (2006).

122. See Judith Resnik, Afterword: Federalism's Options, 14 YALE L. \& Pol'y Rev. 465, 473 (1996) ("My point is not only that particular subject matter may go back and forth between state and federal governance but also that the tradition of allocation itself is one constantly being reworked; periodically, events prompt the revisiting of state or federal authority, and the lines move."). 
outlined both the constitutional principles that a pluralist approach calls forth as well as several examples of pluralist mechanisms already in existence.

A constitutional pluralist jurisprudence of hybridity does not, of course, make it any easier to reach actual decisions in individual cases. Indeed, determining when to defer to a foreign norm and when not, when to allow a margin of appreciation and when not, when to carve out zones of autonomy and when to encroach on them: these are all issues that are probably impossible ever to resolve satisfactorily. And I do not suggest that merely adopting a more inclusive set of jurisprudential or institutional mechanisms will eliminate clashes among normative communities. Such clashes are both inevitable and unlikely ever to be dissolved.

But the relevant question, it seems to me, is not whether law can eliminate conflict, but whether it has a chance of mediating disputes among multiple communities. And this question becomes increasingly important as normative communities increasingly overlap and intersect. Accordingly, instead of bemoaning the messiness of jurisdictional overlaps, we should accept them as a necessary consequence of the fact that communities cannot be hermetically sealed off from each other. Moreover, we can go further and consider the possibility that this jurisdictional messiness might, in the end, provide important systemic benefits by fostering dialogue among multiple constituencies, authorities, levels of government, and nonstate communities. In addition, jurisdictional redundancy allows alternative ports of entry for strategic actors who might otherwise be silenced.

Most fundamentally, all of this interaction is elided or ignored if we continue to think and speak as if legal and quasi-legal spheres can be formally differentiated from each other or as if we will one day all be able to live under a single overarching legal system. Instead, we need to accept and perhaps even celebrate the potentially jurisgenerative and creative role law might play in a plural world. Indeed, it is only if we take multiple affiliation seriously, if we seek dialogue across difference, and if we accept unassimilated otherness that we will have some hope of navigating the hybrid legal spaces that are all around us. 

